\title{
Intercalation of $\mathrm{Mn}^{2+}$ ions onto bentonite clay: implications in groundwater defluoridation
}

\author{
R. Mudzielwana ${ }^{1}$, W. M. Gitari ${ }^{1}$ \& T. A. M. Msagati ${ }^{2}$ \\ ${ }^{1}$ University of Venda, South Africa \\ ${ }^{2}$ University of South Africa, South Africa
}

\begin{abstract}
Fluorosis is a chronic disease caused by drinking water with a fluoride concentration greater than $1.5 \mathrm{mg} / \mathrm{L}$ for extended periods of time. The disease is manifested by tooth decay in dental fluorosis and deformation of bones in skeletal fluorosis. The World Health Organization (WHO) has set fluoride limits in drinking water at $1.5 \mathrm{mg} / \mathrm{L}$. Most rural areas of South Africa depend on groundwater as a source of drinking water. However, groundwater in some of the boreholes has a concentration of fluoride above the permissible limit and will require defluoridation. The present work aims at evaluating the use of $\mathrm{Mn}^{2+}$ intercalated bentonite clay for defluoridation of groundwater. Clay was characterized for mineralogy using X-ray diffraction (XRD) and elemental composition using X-ray fluorescence (XRF) and morphology using scanning electron microscopy (SEM). Batch experiments were conducted to evaluate and optimize various operational parameters such as contact time, adsorbent dose, $\mathrm{pH}$ and initial adsorbate concentration. Optimum operation conditions for adsorption of fluoride were established to be 30 min contact time $1.0 \mathrm{~g} / 100 \mathrm{~mL}$ adsorbent dosage, $3 \mathrm{mg} / \mathrm{L}$ adsorbate concentration and $\mathrm{pH}$ of 2 . Maximum percentage $\mathrm{F}^{-}$ removal of $84.0 \%$ was achieved at optimized conditions. $\mathrm{Mn}^{2+}$ intercalated bentonite clay removed $\approx 55.89 \%$ of fluoride from field water. The study shows that $\mathrm{Mn}^{2+}$ intercalated bentonite clay has potential for application in defluoridation of groundwater.
\end{abstract}

Keywords: batch experiments, fluorosis, bentonite clay, defluoridation. 


\section{Introduction}

Fluoride in drinking water may have beneficial or harmful effects on human health depending on its concentration. Optimal concentration of fluoride in drinking water set by the World Health Organization is at $1.5 \mathrm{mg} / \mathrm{L}$ [1]. A concentration higher than this can lead to fluorosis. The disease is manifested by mottled teeth in dental fluorosis and deformation of bones in skeletal fluorosis [2]. Groundwater in many regions contains fluoride concentration greater than $1.5 \mathrm{mg} / \mathrm{L}$ and will therefore require defluoridation. Various techniques such as precipitation, coprecipitation, ion exchange and adsorption for defluoridation of groundwater have been reviewed by Meenakshi and Maheshwari [3]. Among these techniques, adsorption is widely used because of its viability and sustainability since it uses locally available and cost effective materials. It involves the passage of high fluoride water through an adsorbent bed, where fluoride is removed by physical ion-exchange or surface chemical reaction with adsorbent. Various adsorbents have been tested for fluoride removal, including activated alumina [4], Cuttlefish bones [5], red mud [6] and clay soils [2]. Recently more studies are focusing on the use of clay soils for defluoridation due to their good adsorptive properties such as large specific surface area, chemical and mechanical stability, layered structure and high cation exchange capacity [7]. Bentonite clay belongs to the class of alumino-silicate clay group, which comprises of layers of alumino-silicate sheets. It exhibits a high cation exchange capacity and low permeability [8]. Bentonite has a permanent negative charge caused by the isomorphous substitution of $\mathrm{Al}^{3+}$ for $\mathrm{Si}^{4+}$ in the tetrahedral layer and $\mathrm{Mg}^{2+}$ for $\mathrm{Al}^{3+}$ in the octahedral layer. These negative charges are balanced by the presence of exchangeable cations $\left(\mathrm{Na}^{+}, \mathrm{Ca}^{2+}\right.$ and $\mathrm{K}^{+}$) in the lattice structure, which imparts high cationic exchange to the clay $[9,10]$. Bentonite modified with high ionic density ions such as $\mathrm{Fe}^{3+}, \mathrm{Al}^{3+}$ and $\mathrm{Mg}^{2+}$ has shown higher capacity for anion adsorption. The objectives of the present work are as follows: (1) Physicochemical characterization of raw and $\mathrm{Mn}^{2+}$ modified bentonite, (2) to optimize the loading of $\mathrm{Mn}^{2+}$ onto raw bentonite interlayers, (3) to evaluate the effect of various operating parameters (contact time, adsorbent dosage, adsorbate concentration and $\mathrm{pH}$ ) on the adsorption capacity of $\mathrm{F}^{-}$by $\mathrm{Mn}^{2+}$ modified bentonite clay.

\section{Material and methods}

\subsection{Sample collection}

Bentonite clay used in this project was collected from ECCA Pty (Ltd) in Cape Town. Field water was collected from a community borehole in Siloam, Vhembe district in South Africa. All reagents and TISAB-III were obtained from Rochelle Chemicals \& Lab Equipment CC, South Africa Ltd. A stock solution containing $1000 \mathrm{mg} / \mathrm{L}$ fluoride was prepared by dissolving $2.21 \mathrm{~g}$ Analytical grade sodium fluoride in $1 \mathrm{~L}$ of ultra-pure water $\left(18.2 \mathrm{M} \Omega . \mathrm{cm}^{-1}\right)$ and fluoride solutions for batch experiments were prepared from fresh stock fluoride solution by appropriate 
dilution. $\mathrm{Mn}^{2+}$ stock solution containing $1000 \mathrm{mg} / \mathrm{L}$ was prepared by dissolving $2.29 \mathrm{~g}$ of analytical manganese chloride in $1 \mathrm{~L}$ of ultra-pure water.

\subsection{Preparation and synthesis of $\mathrm{Mn}^{2+}$ modified bentonite clay}

Raw bentonite clay was washed by mixing with ultra-pure water at a ratio of 1:5 in a $1000 \mathrm{~mL}$ beaker, the mixture was stirred for $5 \mathrm{~min}$, and the procedure was repeated twice. After stirring, mixtures were agitated for $15 \mathrm{~min}$ using Stuart reciprocating shaker and then centrifuged for $10 \mathrm{~min}$ at $5000 \mathrm{rpm}$. Samples were then dried in an oven for $12 \mathrm{hrs}$ at $110^{\circ} \mathrm{C}$. Clay samples were then milled to pass through $<250 \mu \mathrm{m}$ sieve. Optimum conditions (i.e., contact time, adsorbate concentration, adsorbent dosage, and $\mathrm{pH}$ ) for modifying bentonite clay with $\mathrm{Mn}^{2+}$ ion were evaluated using batch experiments. The obtained conditions were: $60 \mathrm{~min}$ contact time, $4 \mathrm{~g} / 100 \mathrm{~mL}$ adsorbent dosage, $50 \mathrm{mg} / \mathrm{L} \mathrm{Mn}^{2+}$ adsorbate concentration and initial $\mathrm{pH}$ of 8 . To synthesize $\mathrm{Mn}^{2+}$ modified bentonite, $200 \mathrm{~mL}$ of $50 \mathrm{mg} / \mathrm{L}$ $\mathrm{Mn}^{2+}$ solution was mixed with $8 \mathrm{~g}$ of raw bentonite to make up S/L ratio of $4 \mathrm{~g} / 100$ $\mathrm{mL}$, the $\mathrm{pH}$ of the mixture was then adjusted to 8 using $0.1 \mathrm{M} \mathrm{NaOH}$ and $0.1 \mathrm{M}$ $\mathrm{HCl}$. The mixture was put on a $1 \mathrm{~L}$ Erlenmeyer flask in order to avoid spillage during agitation. The mixture was agitated for $60 \mathrm{~min}$ at $250 \mathrm{rpm}$ on a table shaker and filtered. The solid residue left on the filter paper was dried for $12 \mathrm{hrs}$ at a temperature of $105^{\circ} \mathrm{C}$ in the oven. The modified clay was then milled to pass through $<250 \mu \mathrm{m}$ sieve. The experiments were repeated five times to generate enough $\mathrm{Mn}^{2+}$ modified bentonite for subsequent experiments.

\subsection{Physicochemical and mineralogical characterization}

Mineralogical and chemical composition of $\mathrm{Mn}^{2+}$ bentonite clay was evaluated using XRD and XRF techniques respectively. Surface morphology was determined using Scanning electron microscopy (SEM) (Leo1450 SEM, at 10Kv, working distance $14 \mathrm{~mm}$ ). Properties were compared to those of raw bentonite clay soils.

\subsection{Batch defluoridation experiments}

Batch experiments were carried out to evaluate the effects of contact time, effect of adsorbent dosage, adsorbate initial concentration and the effect of $\mathrm{pH}$ on fluoride adsorption,. The fluoride concentration in the treated samples was measured using an ion selective electrode 9609 BNWP Orion (USA) attached to Thermo Scientific Orion Star ISE/pH/EC meter. Similar ion meter coupled with $\mathrm{pH}$ and $\mathrm{EC}$ electrode was used for measuring $\mathrm{pH}$ and $\mathrm{EC}$ of the treated samples. For residual fluoride, ion selective electrode was calibrated with four standards containing $1 \mathrm{~mL}$ of total ionic strength buffer (TISAB III) per $10 \mathrm{~mL}$ of solution. Same ratio was maintained for the sample. TISAB was added to decomplex $\mathrm{F}^{-}$ from $\mathrm{Al}^{3+}, \mathrm{Fe}^{3+}$ and $\mathrm{Si}^{4+}$ fluorocomplexes and to maintain $\mathrm{pH}$ at between 5.2 and 5.5. All experiments were conducted in triplicate for better accuracy and the mean values were reported. Equations (1) and (2) were used to calculate the percentage removal and adsorption capacity respectively. 


$$
\% \text { removal }=\left(\frac{C_{o}-C_{e}}{C_{o}}\right) \times 100
$$

where: $C_{o}$ is initial fluoride ion concentration and $C_{e}$ is equilibrium fluoride ion concentration.

$$
Q=\left(\frac{C_{o}-C_{e}}{m}\right) \times v
$$

where: $C_{i}=$ initial $\mathrm{F}^{-}$concentration $(\mathrm{mg} / \mathrm{L}), C_{e}=\mathrm{F}^{-}$concentrations at equilibrium $(\mathrm{mg} / \mathrm{L}), V=$ Volume of solution (L) and $m=$ Weight of the adsorbent $(\mathrm{g})$.

\section{Results and discussion}

\subsection{Physicochemical characterization}

\subsubsection{X-ray diffraction analysis}

$\mathrm{X}$ - ray diffraction spectra of raw and $\mathrm{Mn}^{2+}$ modified bentonite clay is presented in Figure 1. Analysis confirms the presence of montmorillonite and quartz as the major minerals and muscovite as one of the trace minerals of bentonite clay. No change in mineralogy of bentonite clay observed after modification with $\mathrm{Mn}^{2+}$ ions.

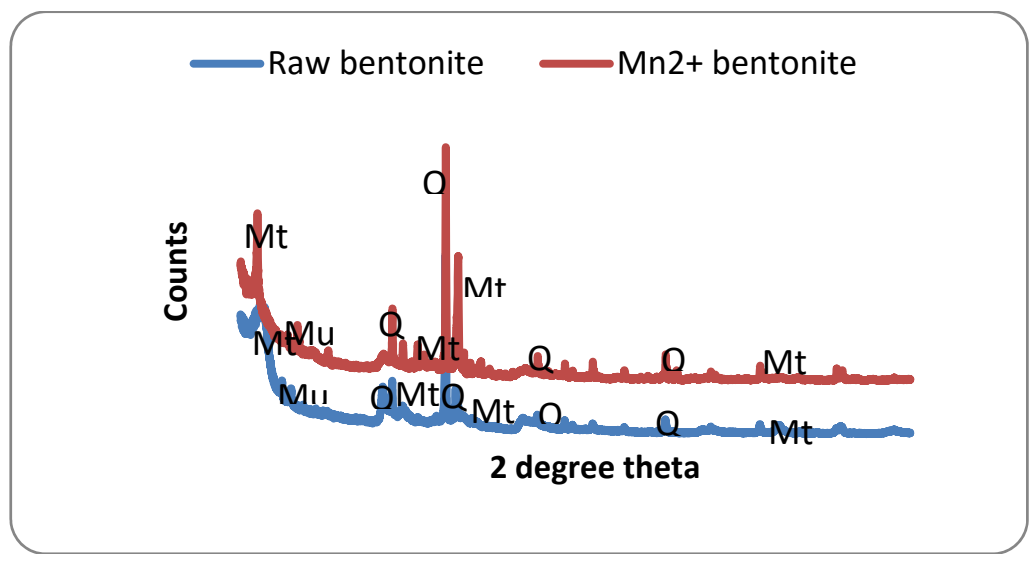

Figure 1: X-ray diffraction spectra for raw and $\mathrm{Mn}^{2+}$ bentonite.

\subsubsection{X-ray fluorescence analysis}

The results for major chemical components are reported as percentage oxide in Table 1 . The analysis reveals that silica $\left(\mathrm{SiO}_{2}\right)$ is the main component of bentonite clay while $\mathrm{Al}_{2} \mathrm{O}_{3}$ is the main minor component. High concentration of $\mathrm{SiO}_{2}$ and $\mathrm{Al}_{2} \mathrm{O}_{3}$ reveal that bentonite clay is an alumino-silicate material. Manganese oxide is higher in $\mathrm{Mn}^{2+}$ bentonite $(0.29 \%)$ than in raw bentonite $(0.09 \%)$. The relatively high concentrations of $\mathrm{MgO}, \mathrm{Na}_{2} \mathrm{O}, \mathrm{CaO}$, and $\mathrm{K}_{2} \mathrm{O}$ indicates that $\mathrm{Mg}^{2+}, \mathrm{Na}^{+}, \mathrm{Ca}^{2+}$, and $\mathrm{K}^{+}$are the main exchangeable cations and main charge balancing cations in the clay interlayers. This is confirmed by the subsequent decrease of the content of these chemical species in the $\mathrm{Mn}^{2+}$ modified bentonite clay. 
Table 1: Chemical composition of raw and $\mathrm{Mn}^{2+}$ modified bentonite clay.

\begin{tabular}{|c|c|c|}
\hline Oxide & $\begin{array}{c}\text { Raw bentonite } \\
(\mathrm{W} / \mathrm{W} \%)\end{array}$ & $\begin{array}{c}\mathrm{Mn}^{2+} \text { bentonite } \\
(\mathrm{W} / \mathrm{W} \%)\end{array}$ \\
\hline $\mathrm{Al}_{2} \mathrm{O}_{3}$ & 15.30 & 15.84 \\
\hline $\mathrm{CaO}$ & 0.88 & 1.50 \\
\hline $\mathrm{Cr}_{2} \mathrm{O}_{3}$ & 0.01 & 0.00 \\
\hline $\mathrm{Fe}_{2} \mathrm{O}_{3}$ & 3.41 & 3.18 \\
\hline $\mathrm{K}_{2} \mathrm{O}$ & 0.98 & 0.39 \\
\hline MgO & 3.20 & 3.06 \\
\hline MnO & 0.06 & 0.29 \\
\hline $\mathrm{Na}_{2} \mathrm{O}$ & 2.12 & 0.94 \\
\hline $\mathbf{P}_{2} \mathbf{O}_{5}$ & 0.09 & 0.04 \\
\hline $\mathrm{SiO}_{2}$ & 66.88 & 62.48 \\
\hline $\mathrm{TiO}_{2}$ & 0.46 & 0.12 \\
\hline L.O.I. & 6.45 & 11.65 \\
\hline Sum of Conc. & 99.89 & 99.49 \\
\hline
\end{tabular}

\subsubsection{Scanning electron microscopy (SEM) analysis}

SEM analysis was conducted to assess the effect of modification on the surface morphology of the bentonite clay. Figure 2 shows the surface morphology of raw and $\mathrm{Mn}^{2+}$ bentonite clay at 20,000x and 40,000x magnification. The analysis reveals that raw bentonite has flat and spongy like material. After the modification

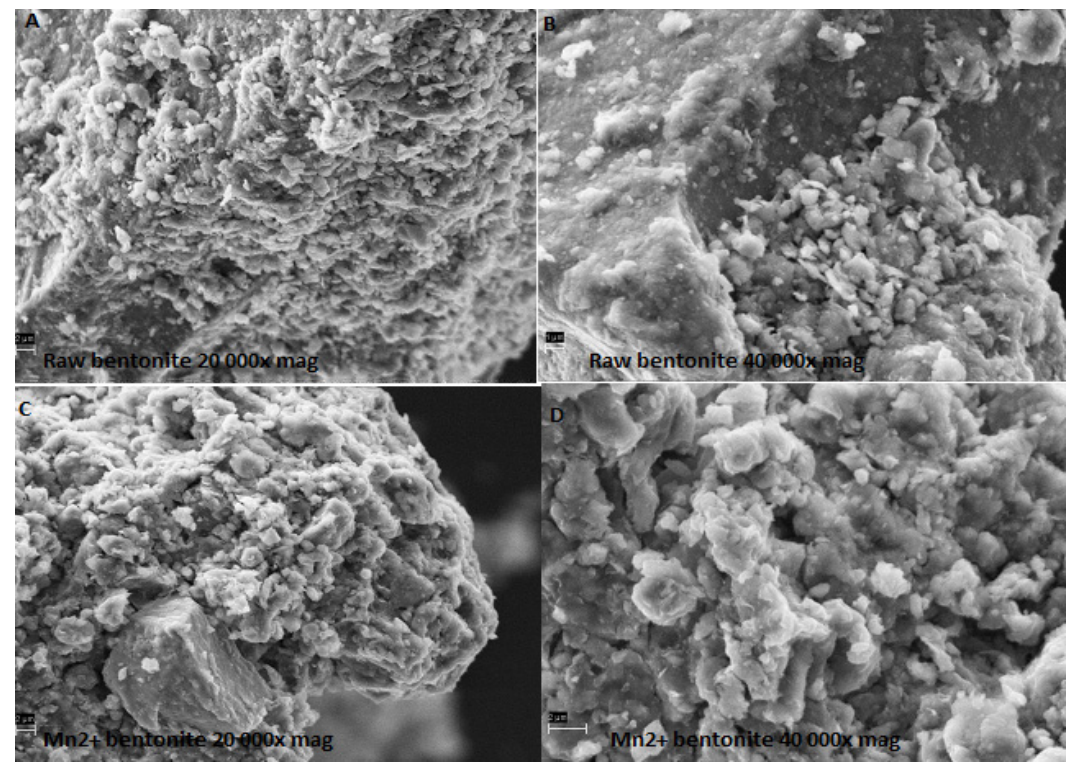

Figure 2: $\quad$ Surficial morphology of raw and $\mathrm{Mn}^{2+}$ modified bentonite. 
of bentonite, the analysis reveals the formation of larger agglomerate and specs on the surface on the surface of clay platelets. This could be due to swelling during the treatment by $\mathrm{Mn}^{2+}$ ions and formation of manganese hydroxides precipitates on the clay surface.

\subsection{Batch experiments}

\subsubsection{Effects of contact time}

The effect of contact time on the adsorption of $\mathrm{F}^{-}$onto $\mathrm{Mn}^{2+}$ bentonite clay was evaluated by varying contact time from 5 to $270 \mathrm{~min}$ at various adsorbent dosages $(0.1,0.3,0.5 \mathrm{~g} / 100 \mathrm{~mL}), 3 \mathrm{mg} / \mathrm{L}$ initial $\mathrm{F}^{-}$concentration, $\mathrm{pH} 5.54 \pm 0.5$ and $250 \mathrm{rpm}$ shaking speed. The results are represented in Figure 3.

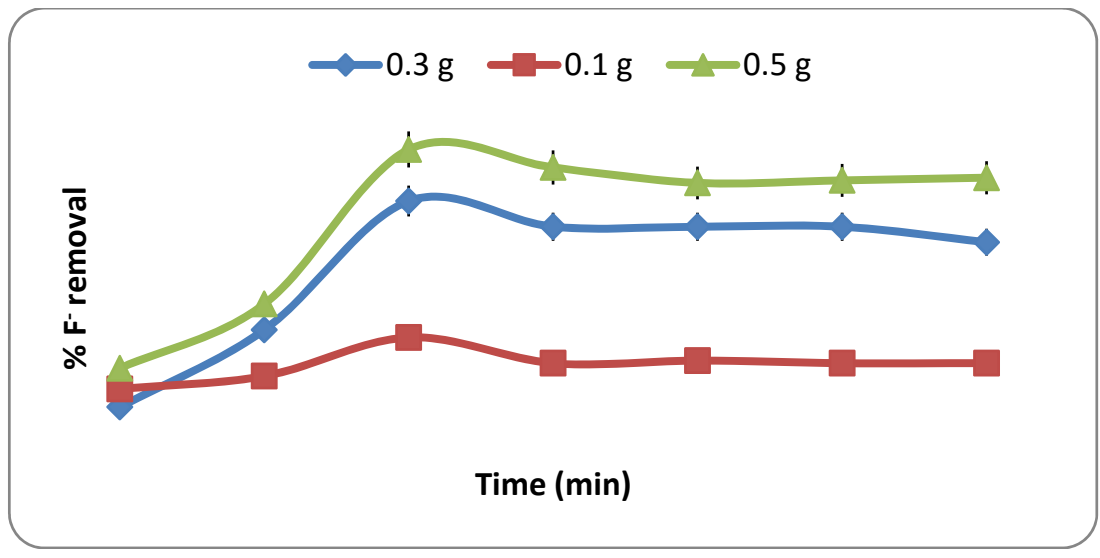

Figure 3: Effect of contact time on $\% \mathrm{~F}^{-}$removal.

From the results in fig. 3 it is observed that $\mathrm{F}^{-}$removal was rapid during the first $30 \mathrm{~min}$ of the experiment where optimum uptake of $\mathrm{F}^{-}$was achieved and thereafter decreased gradually up to 60 min thereafter no significant change in percentage $\mathrm{F}^{-}$removal was observed indicating that equilibrium was reached within $30 \mathrm{~min}$. The increase in fluoride removal may be attributed to the availability of sorption sites in the adsorbent and the decrease may be due to the saturation of the adsorbent surface with time. The same trend was observed at other adsorbent dosages. The percentage $\mathrm{F}^{-}$removal was also observed to be increase with increase in adsorbent dosage. Contact time of 30 min was taken as the optimum time and was applied in subsequent experiments.

\subsubsection{Effect of adsorbent dosage}

The effect of adsorbent dosage on the adsorption of $\mathrm{F}^{-}$onto $\mathrm{Mn}^{2+}$ bentonite clay was evaluated at $30 \mathrm{~min}$ contact time at shaking speed of $250 \mathrm{rpm}, 3 \mathrm{mg} / \mathrm{L}$ initial concentration of $\mathrm{F}^{-}$and $\mathrm{pH}$ of $5.54 \pm 0.5$. The adsorbent dosage was varied from $0.1 \mathrm{~g} / 100 \mathrm{~mL}$ to $2 \mathrm{~g} / 100 \mathrm{~mL}$. The plot of percentage fluoride removal and adsorption capacity against adsorbent dosage is presented in Figure 4. 


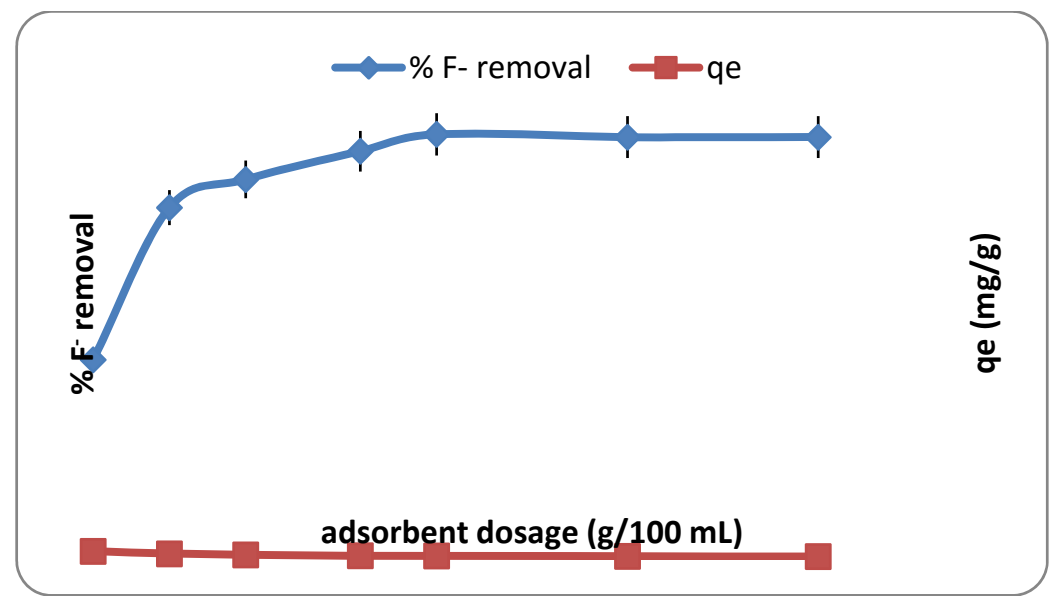

Figure 4: Effect of adsorbent dosage on $\% \mathrm{~F}^{-}$removal.

Figure 4 shows the relationship between percentage fluoride removal, adsorption capacity and adsorbent dosage. It is observed that percentage fluoride removal onto $\mathrm{Mn}^{2+}$ modified bentonite clay increased with an increase in the adsorbent dosage from 0.1 up to $1 \mathrm{~g} / 100 \mathrm{~mL}$ were optimum uptake occurred. This may be attributed to the increase in the sorption sites for fluoride ions as the adsorbent dosage increases. No significant change observed after $1 \mathrm{~g} / 100 \mathrm{~mL}$ adsorbent dosage this may be attributed to too many sites are available for limited quantity of adsorbate. The adsorption capacity on the other hand decreased with increase in adsorbent dosage. At the dosage of $1 \mathrm{~g} / 100 \mathrm{~mL}$, about $50 \%$ of fluoride was removed and this dosage was taken as the optimum and was used in subsequent experiments.

\subsubsection{Effect of adsorbate concentration}

The effect of initial concentration in the adsorption of $\mathrm{F}^{-}$onto $\mathrm{Mn}^{2+}$ bentonite clay was evaluated at various contact times $(30,60$ and $120 \mathrm{~min})$, at $250 \mathrm{rpm}$ shaking speed, $1.0 \mathrm{~g} / 100 \mathrm{~mL}$ adsorbent dosage and $\mathrm{pH}$ of $5.54 \pm 0.5$. The initial concentration was varied from $3 \mathrm{mg} / \mathrm{L}$ to $25 \mathrm{mg} / \mathrm{L}$. Plot of percentage removal with adsorbate concentration is presented in Figure 5.

Figure 5 shows the effect of adsorbate concentration on the percentage fluoride removal at various contact times, it is observed that the percentage removal decreased with an increase in the initial concentration, the same trend was observed at other contact times. This is due to availability of more fluoride ions in solution at higher concentration and the adsorption sites become the limiting factor in the adsorption process. At contact times $>30 \mathrm{~min}$ the adsorption capacity was lower, this was earlier observed in the contact time experiments where maximum absorption was at $30 \mathrm{~min}$. Initial adsorbate of $3 \mathrm{mg} / \mathrm{L}$ was taken as the optimum concentration for subsequent experiments. 


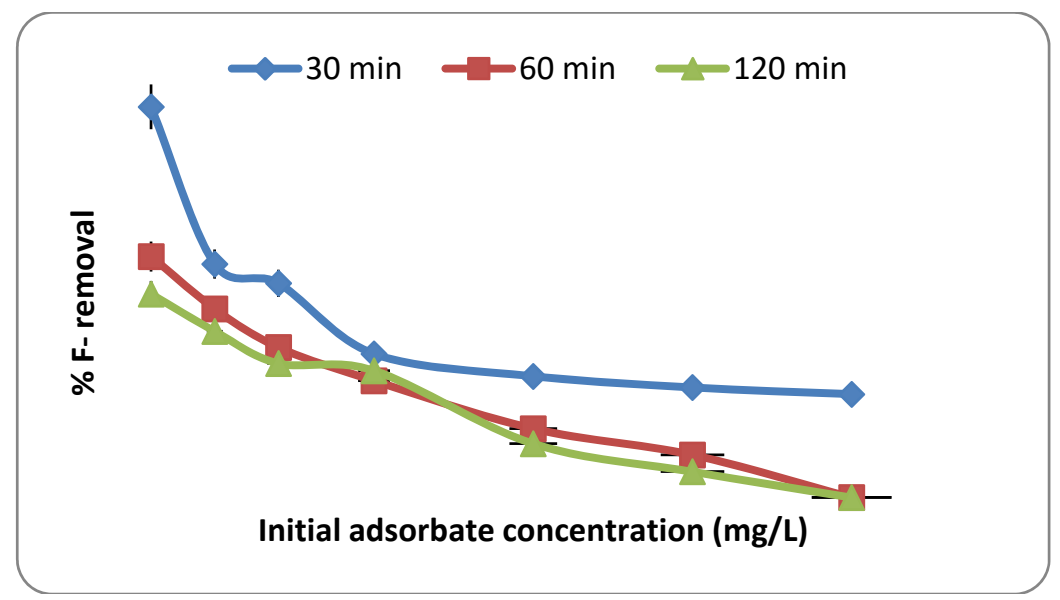

Figure 5: Effect of adsorbate concentration of $\% \mathrm{~F}^{-}$removal.

\subsubsection{Effects of $\mathrm{pH}$}

To study the effects of $\mathrm{pH}$ in the adsorption of $\mathrm{F}^{-}$onto $\mathrm{Mn}^{2+}$ bentonite clay, the initial $\mathrm{pH}$ was adjusted from 2 to 12 using $0.1 \mathrm{M} \mathrm{NaOH}$ and $0.1 \mathrm{M} \mathrm{HCl}$. The effect of $\mathrm{pH}$ was evaluated under the condition of 30 min contact time at $250 \mathrm{rpm}$, $1.0 \mathrm{~g} / 100 \mathrm{~mL}$ adsorbent dosage, $3 \mathrm{mg} / \mathrm{L}$ initial concentration. The plot of $\mathrm{pH}$ with percentage $\mathrm{F}^{-}$removal is shown in Figure 6.

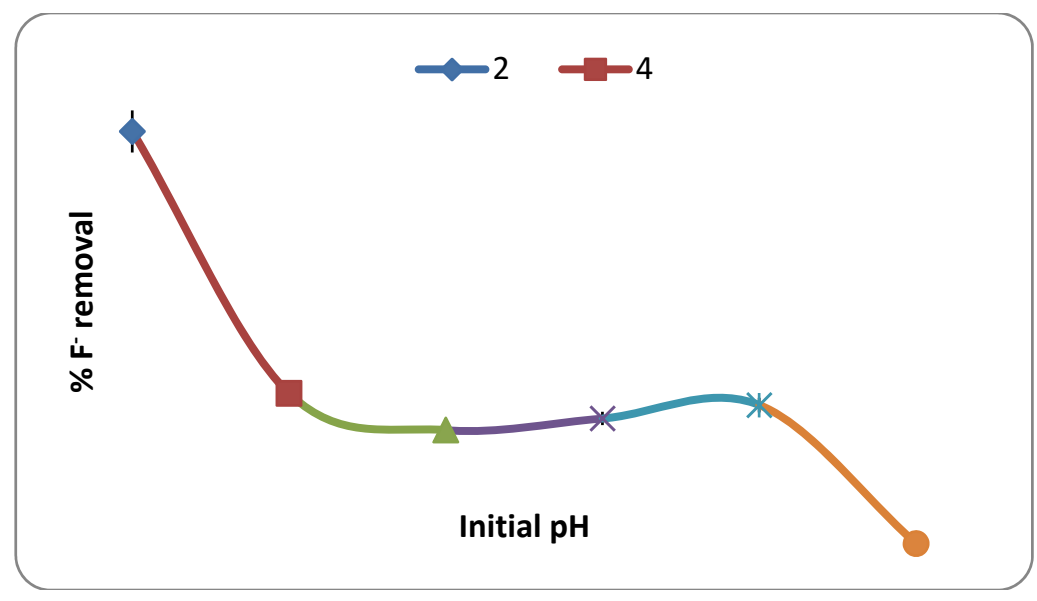

Figure 6: Effect of $\mathrm{pH}$ on $\% \mathrm{~F}^{-}$removal.

$\mathrm{pH}$ of the medium is the most important parameter that influences the fluoride removal and helps in elucidating fluoride uptake mechanisms of the adsorbent. From the results in Figure 6, it is observed that \% fluoride removal decreases with an increase in initial $\mathrm{pH}$, from $84 \%$ removal at $\mathrm{pH} 2$ to $24.33 \%$ at $\mathrm{pH} 6$, thereafter 
a slight increase was observed up to $30 \%$ at $\mathrm{pH} 10$. The drastic decrease in $\mathrm{F}^{-}$ removal was observed at $\mathrm{pH}$ beyond 10 . This may be due to the abundance of $\mathrm{OH}^{-}$ ions in alkaline $\mathrm{pH}$ that compete with $\mathrm{F}^{-}$for adsorption sites. Fluoride adsorption onto $\mathrm{Mn}^{2+}$ bentonite occurred via ligand exchange at lower $\mathrm{pH}$ and ion exchange at higher $\mathrm{pH}$.

\section{Defluoridation of field water}

The effectiveness of $\mathrm{Mn}^{2+}$ bentonite clay in fluoride removal was tested on field water from Siloam community borehole containing $5.4 \mathrm{mg} / \mathrm{L}$ fluoride ion concentration. Field water was treated at its natural $\mathrm{pH}$, adsorbent dosage 1.0 $\mathrm{g} / 100 \mathrm{~mL}$ and the mixture was agitated for $30 \mathrm{~min}$ at $250 \mathrm{rpm}$ shaking speed. Results are presented in Table 2.

Table 2: $\quad$ Physicochemical parameters of field water before and after treatment.

\begin{tabular}{lcc}
\hline \multicolumn{1}{c}{ Parameters } & Before treatment & $\begin{array}{c}\text { After treatment (initial } \\
\text { pH adjusted to 2) }\end{array}$ \\
\hline $\mathrm{pH}$ & 8.62 & 3.2 \\
Conductivity $(\mu \mathrm{S} / \mathrm{cm})$ & 338 & 402 \\
Total dissolved solids & 203 & 84.1 \\
$(\mathrm{mg} / \mathrm{L})$ & & \\
$\mathrm{F}^{-}(\mathrm{mg} / \mathrm{L})$ & 5.4 & 2.7 \\
$\mathrm{Cl}^{-}(\mathrm{mg} / \mathrm{L})$ & 31.59 & 37.15 \\
$\mathrm{SO}_{4}{ }^{2-}(\mathrm{mg} / \mathrm{L})$ & 11.89 & 11.89 \\
$\mathrm{NO}_{3}{ }^{-}(\mathrm{mg} / \mathrm{L})$ & 1.13 & 2.07 \\
$\mathrm{Br}^{-}(\mathrm{mg} / \mathrm{L})$ & 2.08 & $\mathrm{ND}$ \\
$\mathrm{PO}_{4}{ }^{3-}(\mathrm{mg} / \mathrm{L})$ & 2.67 & $\mathrm{ND}$ \\
\hline
\end{tabular}

$\mathrm{ND}=$ Not detected.

Percentage $\mathrm{F}^{-}$removal of $55.89 \%$ was achieved from field water at optimized conditions this is lower than the percentage $\mathrm{F}^{-}$removal achieved at the same conditions from the synthetic $\mathrm{F}^{-}$solution $(84.0 \%$ ) (Fig. 6). This may be attributed to the competition for adsorbent surface between co-existing anion and $\mathrm{F}^{-}$ion. From Table 2 it is noticed that there was reduction in $\mathrm{Br}^{-}$and $\mathrm{PO}_{4}{ }^{3-}$ ions after defluoridation indicating that they were also adsorbed during the process. The results indicate that the fabricated adsorbent would be suitable for treatment of groundwater with $\mathrm{F}^{-}$concentration $\leq 3 \mathrm{mg} / \mathrm{L}$ to achieve the recommended concentration of $1.5 \mathrm{mg} / \mathrm{L}$. 


\section{Conclusions}

Bentonite clay was successfully modified by intercalation of $\mathrm{Mn}^{2+}$ in the interlayers through ion exchange. Mineralogical characterization revealed main mineral phase in raw and $\mathrm{Mn}^{2+}$ bentonite is montmorillonite. Elemental characterization showed that silica and alumina are the main components in bentonite clay. Optimum conditions for adsorption of $\mathrm{F}^{-}$were established to be $30 \mathrm{~min}$ contact time, $1.0 \mathrm{~g} / 100 \mathrm{~mL}$ adsorbent dosage, $3 \mathrm{mg} / \mathrm{L}$ adsorbate concentration and $\mathrm{pH}$ of 2 . A maximum $\mathrm{F}^{-}$removal of $84.0 \%$ was achieved at the optimized batch conditions. When applied to field water, $\mathrm{Mn}^{2+}$ bentonite removed $55.89 \% \mathrm{~F}^{-}$at field $\mathrm{pH}$ which was lower as compared $84.0 \%$ achieved at $\mathrm{pH} 2$.

\section{References}

[1] World Health Organization (WHO), Guideline for drinking water, World Health Organization. Geneva, 2011.

[2] Coetzee, P.P. Coetzee, L.L. Puka, R. \& Mubeng, S., Characterization of selected South African clays for defluoridation of natural water, Water S.A, 29(3), pp. 331-338, 2003.

[3] Meenakshi, S.K. \& Maheshwari, R.C., Fluoride in drinking water and its removal. Journal of Hazardous Matter, 137(1), pp. 456-463, 2006.

[4] Maliyekaal, S.M. Sharma, A.K. \& Philip, L., Manganese-oxide-coated alumina: a promising sorbent for defluoridation of water, Water Res, 40, pp. 3497-3506, 2006.

[5] Nasr, A.B. Walha, K. Charcosset, C. \& Amar, R.B., 2011. Removal of fluoride ions using cuttlefish bones. Journal of fluoride chemistry, 132, pp. 57-62, 2011.

[6] Lv, G. Wu, L. Liao, L. Zhang, Y. \& Zhaohui, Y., Preparation and characterization of red mud sintered porous materials for water defluoridation. Journal of Applied Clay Science, pp. 1-7, 2012.

[7] Bhattachryya, K.G. \& Gupta, S.S., Adsorption of few heavy metals on natural and modified kaolinite and montmorillonite: A review. Advances in colloid and interface science, 140, pp. 114-131, 2008.

[8] Agnello, V.N., Bentonite, Pyrophyllite and talc in the Republic of South Africa. Department of Minerals and Energy. Directorate: Mineral Economics, Pretoria, pp. 1-69, 2005.

[9] Bradley, G. \& Weils, D. H., Elements of nature. 5th ed. USA: Blackies and Sons, 2004.

[10] Ma, Y., Wang, S.G., Fan, M., Gong, W.X. \& Gao, B.Y., Characteristics and defluoridation performance of granular activated carbons coated with manganese oxides. Journal of Hazardous Materials, 168, pp. 1140-1146, 2012. 